\title{
PERBEDAAN PERSEPSI KONSUMEN ATAS FAKTOR PENENTU TEMPAT BELANJA PADA INDOMARET DAN ALFAMART ( Studi Kasus Pada Masyarakat Kelurahan Mangga Kecamatan Medan Tuntungan )
}

\author{
Dra. Elisabeth, M.Si
}

\begin{abstract}
Abstrak
Tujuan penelitian ini menganalisis perbedaan persepsi konsumen atas faktor penentu tempat belanja mengenai produk, lokasi, harga, kenyamanan berbelanja, iklan, dan pelayanan karyawan yang terdapat di Indomaret dan Alfamart dan menganalisis beberapa macam faktor yang menjadi keunggulan Indomaret dan Alfamart untuk dapat bersaing dengan ritel- ritel lain yang terdapat di Kelurahan Mangga Kecamatan Medan Tuntungan. Jumlah sampel 200 responden, metode pengumpulan data melalui koesioner dan dokumentasi, variabel yang diteliti tentang persepsi konsumen atas faktor penentu tempat belanja mengenai produk, lokasi, harga, kenyamanan berbelanja, iklan, dan pelayanan karyawan yang dimiliki oleh Indomaret dan Alfamart, metode analisis data dengan chisquare. Hasil penelitian menunjukkan bahwa ada perbedaan persepsi konsumen Indomaret dengan persepsi konsumen Alfamart pada indikator lokasi, kelengkapan produk yang ditawarkan, harga dan iklan. Perbedaan yang dimaksudkab di atas bahwa Indomaret lebih unggul di bandingkan dengan Alfamart. Sedangkan dari segi kenyamanan berbelanja dan pelayanan yang diberikan mempunyai perbedaan yang signifikan dalam arti Alfamart lebih unggul dibandingkan dengan Indomaret. Berdasarkan hasil pengujian hipotesa dengan Chi- Square $\left(\chi^{2}\right)$ diketahui bahwa terdapat perbedaan yang signifikan antara persepsi konsumen Indomaret dengan persepsi konsumen Alfamart. Hal ini ditunjukkan dengan nilai $\chi 2$ hitung $\left(\chi^{2}=28.4\right)>\chi 2$ tabel $(\chi 2$ tabel $=11,07)$. Bagi pihak manajemen Indomaret sebaiknya menyempurnakan kebijakan yang berhubungan dengan kenyamanan dalam berbelanja seperti kemudahan mobilitas konsumen saat berbelanja dan kualitas pelayanan. Sedangkan bagi pihak Alfamart sebaiknya mengevaluasi kebijakan yang berhubungan dengan produk, lokasi, harga dan iklan.
\end{abstract}

Kata kunci : Produk, Lokasi, Harga, Iklan, Kenyamanan dan Pelayanan

\section{PENDAHULUAN}

Di era globalisasi sekarang ini kegiatan bisnis khususnya pemasaran dari waktu ke waktu semakin meningkat. Banyak sekali perusahaan yang berusaha memenangkan persaingan dengan cara memanfaatkan peluang bisnis yang ada dan berusaha menerapkan strategi pemasaran yang tepat dalam rangka menguasai pasar. Penguasaan pasar merupakan salah satu dari kegiatan-kegiatan pokok yang di lakukan oleh pengusaha untuk mempertahankan hidupnya, berkembang dan mendapatkan laba semaksimal mungkin.

Syarat yang harus di penuhi oleh suatu perusahaan agar dapat sukses dalam persaingan adalah berusaha mencapai tujuan untuk menciptakan dan 
mempertahankan pelanggan dengan membuat citra yang baik di mata pelanggan itu sendiri yang nantinya akan menimbulkan loyalitas yang berkelanjutan. Hal tersebut bisa di capai oleh suatu perusahaan melalui upaya menghasilkan dan menyampaikan barang serta jasa yang diinginkan konsumen, dimana kegiatan tersebut sangat tergantung pada perusahaan atau pedagang dengan bermacam atribut melalui harga, produk, pelayanan umum, lokasi dan perilaku konsumen dalam proses pengambilan keputusan untuk membeli (Engel, 1995:251).

Memilih toko adalah proses interaksi antara strategi pemasaran pengecer dan karateristik individual dan situasional dari pembeli proses ini di gambarkan oleh diagram keputusan pembelian pada umumnya. Karateristik individual seperti gaya hidup menyebabkan pandangan umum tentang aktivitas yang terlibat dalam perilaku berbelanja dan pencarian. Para pengecer mempengaruhi aktifitas ini dengan strategi iklan dan promosi. Karateristik pembeli juga mempengaruhi citra toko. Citra toko pada giliranya mempengaruhi pilihan toko dan produk akhir atau pembelian merek. Jika pengalaman masa lalu memuaskan, maka pilihan akan bersifat kebiasaan. Kecuali jika faktor-faktor lain berubah sejak kunjungan terahir (Engel,1995: 252).

Proses pemilihan toko tertentu merupakan fungsi dari karateristik konsumen dan karateristik toko. Dengan kata lain, tiap pangsa pasar konsumen berbelanja akan memiliki suatu citra dari berbagai toko. Konsumen memilah-milah atau membanding-bandingkan karateristik toko yang di rasakan dengan kriteria evaluasi dari pelanggan inti.

Atribut yang menyolok atau determinan biasanya masuk dari kategori berikut ini : (1) lokasi, (2)sifat dan kualitas pengamanan, (3) harga, (4) iklan dan promosi, (5) personel penjualan,, (6) atribut fisik toko, (7) sifat pelanggan toko, (8) atmosfer toko dan (9) pelayanan dan kepuasan setelah transaksi (Engel,1995:157). Namun di sini peneliti hanya mengambil enam komponen yang paling utama, karena menenurut the use multiatribut attitude model in store image study journal of ritailing para pelanggan potensial yang diminta memilih sepuluh daftar atribut yang ada memilih keenam komponen yang dirasa memiliki pengaruh paling besar dalam menilai citra toko yaitu lokasi, pelayanan, kelengkapan produk yang ditawarkan, harga, iklan, dan kenyamanan berbelanja .

Seiring dengan perkembangan bisnis ritel, pada saat ini bisnis ritel tidak lagi dikelola secara tradisional, melainkan dengan cara modern. Persaingan yang ketat pada bisnis ritel tidak terlepas semakin menjamurnya pusat-pusat perbelanjaan baik yang bersifat lokal, nasional, maupun internasional dengan berbagai faktor yang dibidik. Persaingan tersebut memacu para pebisnis di bidang ritel untuk senantiasa menjadi ritel pilihan konsumen dan mempertahankan konsumennya. Ritel adalah usaha yang menjual produk/ dagangan kebutuhan rumah tangga, termasuk produk kebutuhan sehari - hari yang menggunakan system swalayan (konsumen mengambil barang/ produk itu sendiri tanpa ada yang melayani). Produk merupakan pengetahuan dasar yang harus diketahui oleh seseorang yang bekerja atau mempelajari di bidang bisnis 
ritel. Dengan pengetahuan produk yang baik akan dapat mengembangkan bisnis ritel dan dapat melayani target pasar yang telah ditentukan, dalam hal pemenuhan kebutuhan dan keinginan konsumen.

Di Indonesia terdapat beberapa merek minimarket diantaranya adalah Circle $\mathrm{K}$, Alfamart, Indomaret. Persaingan minimarket di Indonesia sangat ketat dan dapat diihat dari persaingan antara 2 nama besar brand ritel minimarket yaitu Indomaret dan Alfamart. Persaingan antara Indomaret dan Alfamart sangat ketat, kedua brand ritel ternama ini terus bertarung mengerahkan semua kekuatan, kecerdikan dan strategi. Indomaret dimiliki oleh PT Indomarco Prismatama (IP) sebagai salah satu perusahaan dalam industri ritel yang berupa minimarket dan termasuk perusahaan nasional yang bergerak dalam bidang perdagangan umum dan jasa eceran yang menyediakan kebutuhan pokok dan kebutuhan sehari-hari.

Salah satu usaha yang sudah ternama lainya adalah Alfamart. Alfamart adalah jaringan minimarket bahan pokok sehari-hari terkemuka di Indonesia, dengan kualitas tinggi namun tetap terjangkau. Kemajuan Alfamart yang pesat saat ini ditentukan oleh strategi pihak manajemen Alfamart yang tepat dan unik. Alfamart dimiliki oleh PT. Sumber Alfaria Trijaya Tbk. (Alfamart/Perseroan).

Secara teoritis keputusan pembelian yang di lakukan konsumen terhadap barang yang di tawarkan sangat di pengaruhi harga, produk, pelayanan, lokasi perusahaan atau toko (Kotler, 1997: 165). Namun kenyataanya bahwa meski minimarket memiliki karateristik dan strategi yang hampir sama satu dengan yang lainya, kenyataananya dapat memiliki penjualan yang berbeda, seperti Indomart dan Alfamart yang biasanya berdampingan (Tajwini, Rofian, Majalah marketing: 2004). Market share yang berbeda jauh menurut survei AC Nielsen tahun 2005, dari total 5.000 ritel di Indonesia, Alfamart mampu menguasai pangsa pasar sebesar $12.3 \%$. Penguasaan pangsa pasar sebesar itu mendudukkan Alfamart pada posisi nomor empat setelah ritel-ritel yang lain sedangkan Indomaret milik Grup Salim yang menguasai market share sebesar 35\%. Sedangkan menurut penelitian salah satu tabloid bisnis Kontan di kawasan Bekasi Alfamart mampu menguasai pangsa pasar sebesar 33\%. Penguasaan pangsa pasar sebesar itu mendudukkan Alfamart pada posisi nomor dua setelah Indomaret milik Grup Salim yang menguasai market share sebesar 35\% (http://www.kontan.co.id), untuk itu peneliti merasa tertarik untuk melakukan penelitian perbandingan persepsi konsumen toko tersebut mengapa hal tersebut dapat mempengaruhi penjualan padahal keduanya memiliki strategi pemasaran yang hampir sama dan pelayanan yang hampir sama juga adakah perbedaan pada keduanya yang pada ahirnya mempengaruhi citra toko dari kacamata konsumen, apakah yang membuat berhasil mewujudkan kesan yang baik pada pelanggan dan pada ahirnya akan memudahkan meraih konsumen.

Penelitian ini diharapkan dapat mengidentifikasi beberapa pengaruh perbedaan persepsi konsumen dari berbagai faktor pada Indomaret dan Alfamart, untuk meminimalkan kinerja yang baik di Indomaret dan Alfamart. 


\section{Perumusan Masalah}

1. Adakah perbedaan persepsi konsumen atas faktor penentu tempat belanja mengenai produk, lokasi, harga, kenyamanan berbelanja, iklan, dan pelayanan karyawan yang dimiliki oleh Indomaret dan Alfamart?

2. Adakah perbedaan persepsi konsumen atas faktor penentu tempat belanja mengenai produk, lokasi, harga, kenyamanan berbelanja, iklan, dan pelayanan karyawan yang dimiliki oleh Indomaret dan Alfamart ditinjau dari segi jenis kelamin, umur, pekerjaan, dan pendapatan?

\section{TINJAUAN PUSTAKA}

\section{- Pengertian Pemasaran Jasa}

Kegiatan pemasaran tidak terlepas dari fungsi-fungsi organisasi yang lain yang bertujuan menciptakan kepuasan pelanggan. Bauran pemasaran jasa merupakan pengembangan bauran pemasaran. Bauran pemasaran (Marketing Mix) yang hanya mencakup 4P yaitu : (Product, Price, Place dan Promotion). Bauran pemasaran tersebut dikembangkan para ahli pemasaran dengan menambahkan tiga unsur yaitu : People, Process dan Custumer Service (Lupiyoadi (2001).

Menurut Lupiyoadi (2001), Marketing Mix jasa terdiri dari tujuh komponen yaitu : Product (jasa seperti apa yang ingin ditawarkan kepada konsumen), Price (bagaimana strategi penentuan harga), Place (bagaimana system penghantaran/ penyampaian yang akan diterapkan), Promotion (bagaimana promosi yang harus dilakukan), People (tipe kualitas dan kuantitas orang yang akan terlibat dalam pemberian jasa), Process (bagaimana proses dalam operasi jasa), Customer Service (bagaimana pelayanan yang akan diberikan kepada konsumen).

Menurut Yazid (1999), pemasaran jasa adalah perencanaan yang bergerak dari focus pada transaksi menjadi hubungan jangka panjang dengan pelanggan. Sedangkan menurut Lupiyoadi (2001), pemasaran jasa adalah setiap tindakan yang ditawarkan oleh salah satu pihak ke pihak lain yang secara prinsip intangible dan tidak menyebabkan perpindahan kepemilikan apapun. Sedangkan menurut Umar (2002), pemasaran jasa adalah pemasaran yang bersifat intagibel dan immaterial dan dilakukan pada saat konsumen berhadapan dengan produsen. Dari defenisi diatas dapat disimpulkan bahwa pemasaran jasa suatu tindakan yang ditawarkan pihak produsen kepada konsumen dalam arti jasa yang diberikan tidak dapat dilihat, dirasa, didengar atau diraba sebelum dibeli atau dikonsumsi.

\section{- Pengertian Kualitas Pelayanan}

Kualitas pelayanan dapat didefinisikan sebagai seberapa jauh perbedaan antara kenyataan dan harapan para pelanggan atas layanan yang mereka terima. Kualitas pelayanan dapat diketahui dengan cara membandingkan persepsi para pelanggan atas layanan yang benar-benar mereka terima.

Menurut Lewis \& Booms dalam Tjiptono \& Chandra (2005), kualitas pelayanan sebagai ukuran seberapa baik tingkat layanan yang diberikan mampu 
sesuai dengan harapan pelanggan. Sedangkan menurut Tjiptono (2001), kualitas pelayanan adalah tingkat keunggulan yang diharapkan dan pengendalian atas tingkat keunggulan tersebut untuk memenuhi keinginan pelanggan.

Untuk mempermudah penilaian dan pengukuran kualitas pelayanan dikembangkan suatu alat ukur kualitas layanan yang disebut SERVQUAL (service Quality). SERVQUAL ini merupakan skala multi item yang dapat digunakan untuk mengukur persepsi pelanggan atas kualitas layanan yang meliputi lima dimensi (Zeithami, 1990 hal. 143) yaitu :

1. Tangibles (bukti langsung), yaitu kemampuan suatu perusahaan dalam menunjukkan eksistensinya kepada pihak eksternal. Penampilan dan kemampuan sarana dan prasarana fisik perusahaan dan keadaan lingkungan sekitarnya adalah bukti nyata dari pelayanan yang diberikan perusahaan.

2. Reliability (kehandalan) yaitu kemampuan untuk memberikan pelayanan yang dijanjikan dengan segera, akurat dan memuaskan. Kinerja harus sesuai dengan harapan pelanggan yang berarti ketetapan waktu, pelayanan yang sama untuk semua pelanggan tanpa kesalahan, sikap simpatik dan akurasi yang tinggi.

3. Responsiveness (daya tanggap) yaitu kemampuan maskapai penerbangan untuk membantu dan memberikan pelayanan yang cepat (responsif) dan tepat kepada para pelanggan dengan penyampaian informasi yang jelas. Membiarkan pelanggan menunggu tanpa adanya suatu alasan yang jelas menyebabkan persepsi yang negatif dalam kualitas pelayanan.

4. Assurance (jaminan), adanya kepastian yaitu pengetahuan, kesopan satunan dan kemampuan para pegawai perusahaan untuk menumbuhkan rasa percaya para pelanggan kepada pelayanan perusahaan yang memiliki beberapa komponen anatara lain:

a. Communication (komunikasi), yaitu secara terus menerus memberikan informasi kepada pelanggan dalam bahasa dan penggunaan kata yang jelas sehingga para pelanggan dapat dengan mudah mengerti disamping itu perusahaan hendaknya dapat secara cepat dan tanggap dalam menyikapi keluhan dan komplain yang dilakukan oleh pelanggan.

b. Credibility (kredibilitas), perlunya jaminan atas suatu kepercayaan yang diberikan kepada pelanggan, believability atau sifat kejujuran. Menanamkan kepercayaan, memberikan kredibilitas yang baik bagi perusahaan pada masa yang akan datang.

c. Security (keamanan), adanya suatu kepercayaan yang tinggi dari pelanggan akan pelayanan yang diterima. Tentunya pelayanan yang diberikan memberikan suatu jaminan kepercayaan yang maksimal.

d. Competence (kompetensi) yaitu ketrampilan yang dimiliki dan dibutuhkan agar dalam memberikan pelayanan kepada pelanggan dapat dilaksanakan dengan optimal.

e. Courtesy (sopan santun), dalam pelayanan adanya suatu nilai moral yang dimiliki oleh perusahaan dalam meberikan pelayanan kepada pelanggan. 
Jaminan akan kesopan santunan yang ditawarkan kepada pelanggan sesuai dengan kondisi dan situasi yang ada.

5. Empathy (empati), yaitu memberikan perhatian yang tulus dan bersifat individu atau pribadi yang diberikan kepada para pelanggan dengan berupaya memahami keinginan konsumen. Dimana suatu perusahaan diharapkan memiliki pengertian dan pengetahuan tentang pelanggan, memahami kebutuhan pelanggan secara spesifik, serta memiliki waktu pengoperasian yang nyaman bagi pelanggan.

\section{- Pengertian Persepsi}

Menurut Schiffman dan Kanuk (2000:146)"Perception is process by which an individuals selects, organizers, and interprets stimuli into the a meaningfull and coherent picture of the world". Kurang lebihnya bahwa persepsi merupakan suatu proses yang membuat seseorang untuk memilih, mengorganisasikan, dan menginterpretasikan rangsangan-rangsangan yang diterima menjadi suatu gambaran yang berarti dan lengkap tentang dunianya. Sedangkan Kotler dan Amstrong (2008:174) mengemukakan bahwa dalam keadaan yang sama, persepsi seseorang terhadap suatu produk dapat berbeda- beda, hal ini disebabkan oleh adanya proses perceptual (berhubungan dengan ransangan sensorik) yaitu atensi selektif, distorsi selektif dan retensi selektif.

Mowen (Sumarwan, 2003: 70) menyebutkan tahap pemaparan, perhatian dan pemahaman sebagai persepsi dan persepsi ini bersama dengan memori akan mempengaruhi pengolahan informasi. Persepsi setiap orang terhadap suatu obyek akan berbeda-beda. Oleh karena itu persepsi memiliki sifat yang subyektif. Persepsi yang dibentuk seseorang terhadap sesuatu sangat dipengaruhi oleh pikiran dan lingkungannya. Proses pembentukan persepsi dapat dilihat sebagai berikut :

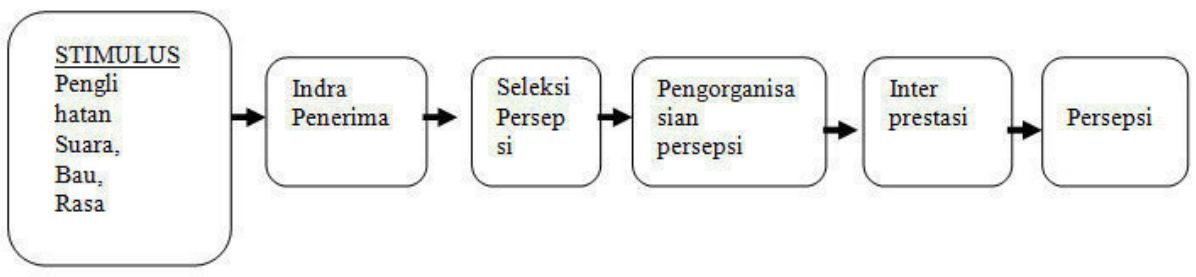

\section{Gambar 2.1 Proses Persepsi}

Sumber : J. Setiadi, Nugroho, 2003, "Perilaku Konsumen Konsep dan Implikasi untuk Strategi dan Penelitian Pemasaran”. Jakarta: Kencana.

\section{a. Seleksi persepsi}

Seleksi persepsi terjadi ketika konsumen menangkap dan memilih stimulus berdasarkan psychological set (berbagai informasi yang ada didalam memorinya) yang 
dimiliki oleh konsumen tersebut. sebelum seleksi persepsi terjadi, terlebih dahulu stimulus harus mendapatkan perhatian dari konsumen. Oleh karena itu konsumen melakukan seleksi terhadap setiap informasi dan stimulus yang diterimanya. Dua proses yang sebenarnya terjadi dalam seleksi perceptual ini adalah perhatian (attention) dan seleksi itu sendiri.

Perhatian yang dilakukan konsumen dapat terjadi secara disengaja (voluntary attention) yaitu ketika konsumen secara aktif mencari informasi yang mempunyai relevansi baginya. Faktor pribadi merupakan faktor pendorong dari perhatian ini dan berada diluar control pemasar. Konsumen secara sengaja akan memberikan perhatian kepada stimulus yang akan membernya solusi yang dibutuhkannya.

Perhatian yang tidak disengaja (involuntary attention) terjadi ketika kepada konsumen dipaparkan sesuatu yang menarik, mengejutkan atau sesuatu hal yang tidak diperkirakan sebelumnya yang tidak ada relevansinya dengan tujuan dan kepentingan konsumen. Faktor ini dapat dikontrol dan dimanipulasi oleh pemasar dengan tujuan utama untuk menarik perhatian konsumen.

\section{b. Pengorganisasian Persepsi}

Pengorganisasian persepsi berarti bahwa konsumen mengelompokkan informasi dari berbagai sumber kedalam pengertian yang menyeluruh untuk memahami lebih baik dan bertindak atas pemahaman itu. Pengorganisasian ini akan memudahkan untuk memproses informasi dan memberikan pengertian yang terintegrasi serta evaluasi terhadap stimulus.

\section{c. Interprestasi Persepsi}

Interprestasi didasarkan pada pengalaman penggunaan suatu produk pada masa lalu dan pengalaman itu tersimpan dalam memori jangka panjang. Pada proses ini konsumen membuka kembali berbagai informasi dalam memori jangka panjangnya (long term memory) yang akan membantu konsumen melakukan evaluasi atas berbagai stimulus. Tahaap inilah yang disebut persepsi konsumen terhadap obyek atau citra produk (product images) sebagai output dari penerimaan konsumen terhadap stimulus. Persepsi konsumen bisa berupa persepsiproduk, persepsi merek, persepsi pelayanan, persepsi harga, persepsi kualitas produk ataupun persepsi terhadap produsen.

\section{- Implikasi Persepsi Terhadap Pemasaran}

Konsumen cenderung untuk membentuk persepsi terhadap merek, toko dan perusahaan didasarkan pada inferensi atau kesimpulan yang mereka peroleh dari stimulus pemasaran dan lingkungan. Citra adalah total persepsi terhadap suatu obyek yang dibentuk dengan memproses informasi dari berbagai sumber setiap waktu. Sasaran penting dari strategi pemasaran adalah untuk mempengaruhi persepsi konsumen terhadap merek, toko dan perusahaan.

a. Citra Merek. Citra merek mempresentasikan keseluruhan persepsi konsumen terhadap merek dan dibentuk dari informasi dan pengalaman masa lalu terhadap merek tersebut. Citra terhadap merek berhubungan dengan sikap berupa keyakinan dan preferensi terhadap suatu merek. Konsumen dengan citra positif terhadap suatu merek lebih memungkinkan untuk melakukan pembelian. Perusahaan perlu memperhatikan bagaimana 
mempertahankan dan meningkatkan citra merek yang sudah positif. Cara yang paling tepat untuk mempengaruhi konsumen adalah dengan melakukan positioning produk dengan menonjolkan keunggulan merek dan produk sesuai dengan konsep produk dan target pasar .

b. Citra Toko. Konsumen mengembangkan citra toko bedasarkan iklan, kelengkapan produk yang merupakan pengalaman berbelanja dan pendapat dari orang lain. Citra toko yang ada dibenak konsumen akan mempengaruhi citra merek secara langsung, sehingga penetapan produk pada rantai pengecer (ritel) merupakan salah satu sarana untuk pembentukan citra.

c. Citra Perusahan. Selain pengembangan persepsi terhadap merek dan toko, konsumen juga memperhatikan berbagai informasi mengenai perusahaan seperti bagaimana pengalaman perusahaan dalam produksi produknya atau bagaimana posisi perusahaan dibandingkan dengan perusahaan lain. Konsumen mempunyai pengalaman yang baik dengan produk yang dihasilkan perusahaan akan membantu persepsi yang baik terhadap perusahaan. Melalui citra positif konsumen ini, perusahaan akan dapat mengembangkan berbagai level produk yang lebih luas untuk diproduksi dan dijual.

\section{- Komunikasi Pemasaran}

Komunikasi pemasaran adalah upaya perusahaan dapat menyampaikan apa yang mereka tawarkan kepada konsumen dan konsumen dapat menerimanya dengan baik. Ada beberapa elemen komunikasi pemasaran yaitu periklanan, penjualan tatap muka (personal selling), kehumasan (public relation) dan pemasaran langsung. Namun dalam konteks pemasaran eceran (retail), bauran pemasaran ini tetap tidak dapat terpisah dengan kondisi-kondisi perusahaan eceran. artinya semua elemen digunakan dengan porsi masing-masing sesuai dengan tujuan masing-masing namun tetap sebagai satu kesatuan. Secara umum tujuan komunikasi pemasaran adalah berusaha memberikan pengaruh dalam pengambilan keputusan pembelian konsumen. Beberapa tahap yang sering terjadi pada konsumen perusahaan eceran sebagai berikut:

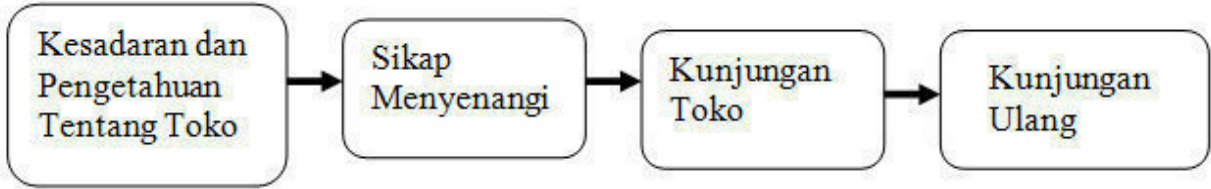

Gambar 2.2: Tahap Perilaku Konsumen Eceran

Sumber : Amir, M. Taufiq. 2005, Dinamika Pemasaran: Jelajahi \& Rasakan, Jakarta: PT. RajaGrafindo Persada. 
Setiap tahapan dalam proses membutuhkan alat komunikasi yang berbeda agar sesuai denagan sasaran perusahaan. Tujuan perusahaan melakukan komunikasi pemasaran adalah.

\section{Untuk Positioning}

Kesan umum atau persepsi harus diciptakan perusahaan dibenak pelanggan dan orang banyak sehingga perusahaan terlihat berbeda atau memiliki diferensiasi dengan perusahaan lain. Tujuan ini bersifat jangka panjang dan biasanya dikaitkan dengan produk, harta ataupun gaya hidup.

a Persepsi kualitas (perceived quality), merupakan persepsi konsumen terhadap keseluruhan kualitas dan keunggulan produk atau merek. Persepsi kualitas merupakan persepsi konsumen secara individual dan tidak dapat ditentukan secara obyektif karena melibatkan apa yang penting bagi masing-masing konsumen yang berbeda terhadap suatu merek. Persepsi kualitas mempunyai peranan penting dalam membangun suatu merek, karena dapat menjadi alasan penting yang diperbandingkan konsumen yang pada gilirannya mempengaruhi konsumen memutuskan merek yang dibeli. Sedemikian pentingnya persepsi kualitas bagi suatu merek sehingga upaya untuk membangun persepsi kualitas yang kuat perlu memperoleh perhatian serius karena peningkatan persepsi kualitas yang diinginkan harus diikuti dengan peningkatan kualitas nyata produk perusahaan.

b. Nilai emosional (emotional value), menurut Forgas (Tjiptono, 2000:125) dalam batas tertentu emosi mempengaruhi pikiran manusia dan mempengaruhi mereka dalam menangani informasi. Demikian juga halnya dengan perilaku konsumen terutama dalam keputusan pembelian. Konsumen membeli dan mengonsumsi produk bukan sekedar karena nilai fungsionalnya tetapi juga karena nilai emosionalnya. Nilai emosional ini mencakup kenikmatan, penciptaan nilai diri, kepuasan dan lain-lain yang berkaitan dengan emosi. Emosi memainkan peranan yang penting dalam proses pengambilan keputusan mulai dari identifikasi masalh sampai pada perilaku paska pembelian karena suatu produk tidak saja memiliki nilai tangible tetapi juga nilai intangible bagi konsumen. Pemahaman mengenai sisi emosional konsumen dapat memberikan manfaat bagi pemasar untuk memberikan gambaran yang lebih utuh mengenai perilaku konsumen.

c. Harga (price), merupakan atribut produk atau jasa yang paling sering digunakan oleh konsumen untuk mengevaluasi dan menilai suatu produk. Untuk kalangan berpendapatan rendah maka harga adalah faktor paling utama yang dipertimbangkan dalam memilih produk. Sebaliknya ada konsumen yang menjadikan harga bukan sebagai faktor utama dalam melakukan pembelian. Secara bersamaan, faktor-faktor ini akan menentukan nilai persepsi konsumen yang akan mereka hubungkan yaitu 
antara kualitas produk dan harga yang akan dibayarkan. Faktor kesesuaian antara harga dan kualitas produk dapat menjadi pertimbangan bagi konsumen untuk membeli atau tidak membeli suatu produk. Konsuen melakukan pembelian dengan mempertimbangkan kualitas karena konsumen memandang adanya kesesuaian harga bila mereka menilai produk yang ditawarkan berdasarkan kualitas yang tinggi dan baik. Sedangkan untuk nilai unik, konsumen memandang adanya kesesuaian harga bila mereka menilai produk memberikan manfaat yang unik dan tidak ada produk pengganti yang sesuai.

2. Untuk peningkatan penjualan. Merupakan tujuan perusahaan yang sifatnya adalah untuk jangka pendek yaitu untuk mendapatkan laba.

\section{- Gerai dan peritel}

Peritel atau pengecer adalah pengusaha yang menjual barang atau jasa secara eceran kepada masyarakat sebagai konsumen (Hendri Maaruf,2005:71). Peritel perorangan atau peritel kecil memiliki jumlah gerai bervariasi, mulai dari satu gerai hingga beberapa gerai. Gerai dalam segala bentuknya berfungsi sebagai tempat pembelian barang dan jasa, yaitu dalam arti konsumen datang ke gerai untuk melakukan transaksi berbelanja dan membawa pulang barang atau menikmati jasa. Gerai-gerai dari peritel kecil terdiri atas dua macam, yaitu gerai modern dan tradisional

Peritel besar adalah peritel berbentuk perusahaan yang melakukan kegiatan perdagangan ritel dalam skala besar, baik dalam arti gerai besar maupun dalam arti mempunyai gerai besar dan sekaligus gerai kecil. Perusahaan perdagangan ritel besar dapat memiliki format bervariasai dari yang terbesar (perkulakan) hingga yang terkecil atau minimarket ( Hendri Ma'ruf, 2005:71).

1). Gerai tradisional

Gerai tradisional Adalah gerai yang telah lama beroperasi di negeri ini berupa: warung, toko, dan pasar. Warung biasanya berupa bangunan sederhana yang permanen (tembok penuh) semi permanen (tembok setinggi 1 meter di sambung papan sebagai dinding), atau dinding kayu seutuhnya.. Menurut penelitian AC Nilsen, selama 10 tahun sampai 2002, telah tumbuh 1 juta warung yang kebanyakan di luar kota dengan omzet rata-rata Rp 100.000 per hari.

2). Gerai modern

Gerai modern mulai beroperasi awal 1960-an di Jakarta, arti modern di sini adalah penataan barang menurut keperluan yang sama di kelompokan di bagian yang sama yang dapat dilihat dan diambil langsung oleh pembeli, penggunaan alat pendingin udara, dan adanya pramuniaga profesional.

Modernisasi bertambah meluas pada dasawarsa 1970-an. Supermarket mulai di perkenalkan pada dasawarsa ini, konsep one stop shopping mulai dikenal pada dasawarsa 1980-an yang kemudian menjadi popular awal 1990-an. 
Istilah pusat belanja mulai popular di gunakan untuk mengganti kata one stop shopping. Banyak orang mulai beralih ke gerai modern seperti pusat belanja ini untuk berbelanja. Macam- macam gerai modern diantaranya (Philip Kotler,1997:337-339):

a) Minimarket terjadi pertumbuhan sebanyak 1800 buah selama 10 tahun sampai 2002. Luas ruang minimarket adalah antar $50 \mathrm{~m}^{2}$ sampai $200 \mathrm{~m}^{2}$.

b) Convenience store: gerai ini mirip minimarket dalam hal produk yang dijual, tetapi berbeda dalam hal harga, jam buka, dan luas ruangan,dan lokasi. Convenience store ada yang dengan luas ruangan antara $200 \mathrm{~m}^{2}$ hingga $450 \mathrm{~m}^{2}$ dan brelokasi di tempat yang setrategis, dengan harga yng lebih mahal dari harga minimarket.

c) Special store: merupakan toko yang memiliki persediaan lengkap sehingga konsumen tidak perlu pindah toko lain untuk membeli sesuatu harga yang bervariasi dari yang terjangkau hingga yang mahal.

d) Factory outlet

e) Distro

f) Supermarket: mempunyai luas $300-1100 \mathrm{~m}^{2}$ yang kecil sedang yang besar $1100-2300 \mathrm{~m}^{2}$

g) Perkulakan atau gudang rabat

h) Super store: adalah toko serba ada yang memiliki variasi barang lebih lengkap dan luas yang lebih besar dari super market

i) Hipermarket: luas ruangan di atas $5000 \mathrm{~m}^{2}$

j) Pusat belanja yang terdiri dua macam yaitu mall dan trade center.

\section{- Minimarket}

Minimarket adalah toko swalayan yang hanya memiliki satu atau dua mesin register (http// www.sinarharapan.co.id). Sedang menurut Hendri ma'aruf (2005:76) yang di sebut minimarket biasanya luas ruanganya adalah antar $50 \mathrm{~m}^{2}$ sampai $200 \mathrm{~m}^{2}$ serta berada pada lokasi yang mudah dijangkau konsumen. Mini market mengisi kebutuhan masyarakat akan warung yang berformat modern. dengan mini market, belanja sedikit di tempat yang dekat dan nyaman terpenuhi, perilaku konsumen yang menyukai tempat belanja bersih, sejuk, dan tertata rapi membuat minimarket menjadi lebih unggul dari warung dan toko. 
Tabel 1. Pangsa pasar Hipermarket,supermarket, minimarket, pasar tradisional di Indonesia

\begin{tabular}{|l|l|l|l|l|}
\hline & 2000 & 2001 & 2002 & 2003 \\
\hline Hipermarket \& supermarket & $16,7 \%$ & $20,5 \%$ & $20,2 \%$ & $21,1 \%$ \\
\hline Minimarket & $3,4 \%$ & $4,6 \%$ & $4,6 \%$ & $5,1 \%$ \\
\hline Pasar trdisional & $79,8 \%$ & $74,9 \%$ & $74,9 \%$ & $73,8 \%$ \\
\hline
\end{tabular}

Sumber: Sisipan bisnis Indonesia “ arah bisnis dan politik”, Desember 2003

Perusahaan yang pertama kali menggunakan format minimarket sebagai strategi bisnis di Indonesia adalah PT. Indomarco Prismatama yang pada tahun 1988 mendirikan minimarketnya yang pertama. Pada ahir tahun 2003 jumlah gerai indomaret 796 unit di Jabodetabek, Bogor, Bandung, Semarang dan Surabaya, Indomarco merencanakan mendirikan 600 toko lagi di tahun 2005 (http//www.kontan-online.com Inc: 2004).

Perusahaan lain yang juga mengoperasikan minimarket adalah Alfaria Trijaya yang pada tahun 2004 telah memiliki 923 gerai dengan nama alfamart dan merencanakan mengembangkan menjadi 1800 unit di seluruh Indonesia tahun 2005 (http//www.kontan-online.com Inc: 2004).

Minimarket yang masuk dalam kelompok seperti alfamart dan Indomaret baik yang dimiliki perusahaan atau yang waralaba atau hanya operasional saja tergolong sebagai chain store yaitu toko atau gerai yang terhimpun di bawah satu nama dengan sistem yang sama termasuk dalam kegiatan pemasaranya, istilah lain dari chain store adalah multiples, istilah yang di pake di Inggris. Persaingan minimarket telah memunculkan peritel-pertel kecil dengan satu atau beberapa gerai .

\section{METODE PENELITIAN}

\section{- Populasi dan Sampel}

Populasi dalam penelitian ini, seluruh masyarakat Kelurahan Mangga Kecamatan Medan Tuntungan. Teknik pengambilan sampel dengan Teknik Cluster Sampling adalah dimana pemilihannya mengacu pada kelompok bukan pada individu. Dalam penelitian ini, peneliti menetapkan jumlah sampel 200 orang yang dipilih dari masyarakat Kelurahan Mangga Kecamatan Medan Tuntungan. Kelurahan Mangga Kecamatan Medan Tuntungan terdiri dari 10(sepuluh) lingkungan yaitu lingkungan $1 \mathrm{~s} / \mathrm{d} 10$ maka jumlah anggota sampel yang dipilih setiap lingkungan 20 orang. Maka jumlah cluster yang diambil adalah $200: 20=10$, kemudian dipilih secara acak dari 10 lingkungan 20 orang sebagai anggota sampel. 


\section{- Operasionalisasi Variabel}

Operasionalisasi variabel dalam penelitian ini yaitu :.

1. Produk. Produk ( product ) menurut Kotler \& Armstrong, (2001: 346) adalah segala sesuatu yang dapat ditawarkan ke pasar untuk mendapatkan perhatian, dibeli, digunakan, atau dikonsumsi yang dapat memuaskan keinginan atau kebutuhan. Secara konseptual produk adalah pemahaman subyektif dari produsen atas sesuatu yang bisa ditawarkan sebagai usaha untuk mencapai tujuan organisasi melalui pemenuhan kebutuhan dan kegiatan konsumen, sesuai dengan kompetensi dan kapasitas organisasi serta daya beli pasar. Selain itu produk dapat pula didefinisikan sebagai persepsi konsumen yang dijabarkan oleh produsen melalui hasil produksinya.

2. Lokasi . Lokasi/ Tempat - Menurut Swastha (2002:24) "Lokasi adalah tempat dimana suatu usaha atau aktivitas usaha dilakukan". Faktor penting dalam pengembangan suatu usaha adalah letak lokasi terhadap daerah perkotaan, cara pencapaian dan waktu tempuh lokasi ke tujuan. Faktor lokasi yang baik adalah relatif untuk setiap jenis usaha yang berbeda.

3. Harga. Harga menurut Kotler dan Armstrong (2001: 439) adalah sejumlah uang yang dibebankan atas suatu produk atau jasa, atau jumlah dari nilai yang ditukar konsumen atas manfaat-manfaat karena memiliki atau menggunakan produk atau jasa tersebut.

4. Iklan. Iklan yaitu kegiatan memberitahukan atau menginformasikan suatu hal, barang, atau jasa melalui media massa baik online maupun ofline. Media yang digunakan, antara lain televisi, radio, koran, majalah, internet, hp, poster, pamflet, brosur, spanduk dan sebagainya".

5. Kenyamanan . Menurut Kolcaba (2003) menjelaskan bahwa kenyamaan sebagai suatu keadaan telah terpenuhinya kebutuhan dasar manusia yang bersifat individual dan holistik. Dengan terpenuhinya kenyamanan dapat menyebakan perasaan sejahtera pada diri individu tersebut.

6. Pelayanan. Pelayanan ialah menolong untuk menyediakan segala sesuatu yang diperlukan oleh orang lain diataranya adalah pembeli. Pelayanan dapat diberikan kepada orang lain sebagai pertolongan yang dibutuhkan orang lain itu sendiri. Yang mana dengan pertolongan tersebut dapat membantu orang lain untuk bisa mengatasi masalahnya.

\section{- Teknik Pengumpulan Data}

Teknik pengumpulan data yang digunakan dalam penelitian ini adalah:

1. Kuesioner, dilakukan dengan membagikan angket kepada responden yang berguna untuk mengetahui persepsi pelanggan mengenai produk, lokasi, harga, kenyamanan, iklan dan pelayanan karyawan yang ada di Indomaret dan Alfamart.

2. Teknik dokumentasi, dilakukan dengan mengumpulkan data yang sudah diolah sebelumnya dari Indomaret dan Alfamart. 


\section{- Teknik Analisis}

Metode analisis data yang digunakan dalam penelitian yaitu teknik analisis Chi Square. Uji chi-square di sebut juga dengan Kai Kuadrat. Uji chi-squeare adalah salah satu uji statistic no-parametik (distibusi dimana besaran - besaran populasi tidak diketahui) yang cukup sering digunakan dalam penelitian yang menggunaka dua variable, dimana skala data kedua variable adalah nominal atau untuk menguji perbedaan dua atau lebih proporsi sampel. Uji chi-square diterapkan pada kasus dimana akan diuji apakah frekuensi yang akan diamati (data observasi) untuk membuktikan atau ada perbedaan secara nyata atau tidak dengan frekuensi yang diharapkan. Chi-square adalah teknik analisis yang digunakan untuk menentukan perbedaan frekuensi observasi (Oi) dengan frekuensi ekspektasi atau frekuensi harapan (Ei) suatu kategori tertentu yang dihasilkan. Uji chi-square dirumuskan sebagai berikut :

$$
\chi^{2}=\left[\frac{\sum\left(f_{0}-f_{e}\right)^{2}}{f_{e}}\right]
$$

Keterangan :

$\chi^{2}=$ Nilai chi-kuadrat

$\mathrm{f}_{\mathrm{e}}=$ Frekuensi yang diharapkan

$\mathrm{f}_{\mathrm{o}}=$ Frekuensi yang diperoleh/diamati

\section{HASIL PENELITIAN DAN PEMBAHASAN}

\section{- Karateristik Responden}

\section{a. Responden Menurut Jenis Kelamin}

Berdasarkan hasil penelitian yang telah dilakukan, data yang didapat dari penyebaran angket diperoleh data jenis kelamin responden yang ditunjukan pada tabel berikut:

Tabel 2. Karateristik Responden Menurut Jenis Kelamin

\begin{tabular}{|l|c|c|c|}
\hline No & Jns kelamin & Jml responden & $\%$ \\
\hline 1. & Pria & 143 orang & $46 \%$ \\
2. & Wanita & 157 orang & $54 \%$ \\
\hline
\end{tabular}

Sumber : Data primer diolah, tahun 2017

Pada tabel di atas menunjukan, bahwa yang berbelanja di Indomaret dan Alfamart lebih dominan kaum wanita daripada laki-laki.

\section{b. Responden Menurut Jumlah Pendapatan}

Berdasarkan hasil penelitian yang telah dilakukan, data yang didapat dari penyebaran angket diperoleh data jumlah pendapatan responden yang ditunjukan tabel berikut: 
Tabel 3. Karateristik Responden Menurut Jumlah Pendapatan

\begin{tabular}{|l|l|l|c|}
\hline \multicolumn{1}{|c|}{ No } & \multicolumn{1}{|c|}{ Jumlah pendapatan } & \multicolumn{1}{|c|}{ Jumlah responden } & $\%$ \\
\hline 1. & Kurang dari 1 juta & 67 orang & $34 \%$ \\
2. & 1 juta $-2,5$ juta & 85 orang & $43 \%$ \\
3. & 2,5 juta -5 juta & 48 orang & $24 \%$ \\
\hline
\end{tabular}

Sumber : Data primer diolah, tahun 2017

Pada tabel di atas menunjukan, bahwa yang berbelanja di Indomaret dan Alfamart lebih dominan yang berpendapatan 1 juta -2.5 juta.

\section{c. Responden Menurut usia}

Berdasarkan hasil penelitian yang telah dilakukan, data yang didapat dari penyebaran angket diperoleh data usia responden yang ditunjukan tabel berikut :

Tabel 4. Karateristik Responden Menurut Usia

\begin{tabular}{|c|c|c|c|}
\hline No & Usia & Jumlah responden & $\%$ \\
\hline 1. & Kurang dari 20 tahun & 20 orang & $10 \%$ \\
2. & 20 thn -30 thn & 60 orang & $30 \%$ \\
3. & 31 thn -40 thn & 64 orang & $32 \%$ \\
4. & 41 thn -50 thn & 30 orang & $15 \%$ \\
5. & lebih dari 51 & 26 orang & $13 \%$ \\
\hline
\end{tabular}

Sumber : Data primer diolah, tahun 2017

Pada tabel di atas menunjukan, bahwa yang berbelanja di Indomaret dan Alfamart lebih dominan yang berusia 31 tahun -40 tahun.

\section{- Analisis Hasil Penelitian}

Analisis yang digunakan dalam penelitian ini ada 2 menggunakan analisis deskriptif, dan analisis uji beda dengan uji-t dengan program spss. Hasil dari perhitungan menggunakan SPSS dengan ringkasan perhitungan sebagai berikut :

a. Perhitungan analisis deskriptif:

Perbandingan persepsi Indomaret dan Alfamart dengan analisis deskriptif dapat dilihat pada tabel di bawah ini :

Tabel 17. Perhitungan Rata-Rata Prosentase Minimarket Indomaret dan Alfamart

\begin{tabular}{|l|c|c|}
\hline Keterangan & Indomaret & Alfamart \\
\hline Lokasi & $69 \%$ & $62 \%$ \\
\hline Kelengkapan produk & $69 \%$ & $68 \%$ \\
\hline Harga & $68 \%$ & $51 \%$ \\
\hline Promosi & $71 \%$ & $66 \%$ \\
\hline Kenyamanan & $46 \%$ & $56 \%$ \\
\hline Pelayanan & $61 \%$ & $70 \%$ \\
\hline
\end{tabular}

Sumber : Data primer diolah tahun 2017 
Dari perhitungan variabel di atas dapat diketahui bahwa keunggulan dari Indomaret yaitu pada lokasi yang tersebar, faktor-faktor kelengkapan produk yang ditawarkan, harga yang ditawarkan dan iklan yang disampaikan sedangkan keunggulan dari Alfamart yaitu kenyamanan dan pelayanan dalam melayani pelanggannya.

\section{b. Perhitungan menggunakan uji- Chi- Square $\left(\chi^{2}\right)$}

Langkah - langkah Pengujian :

1. Rumuskan Hipotesis nihil (Ho) dan alternatif (Ho)

Ho $: \chi^{2}=0$ Tidak ada perbedaan

$\mathrm{H} 1: \chi^{2} \neq 0$ Ada perbedaan

2. Buat Tabel Kontingensi

Tabel kontingensi berbentuk 2x6 ( 2 baris dan 6 kolom). Setiap kotak disebut sel, setiap sebuah kolom berisi sebuah subvariabel, setiap sebuah baris berisi sebuah subvariabel.

Tabel 18. Frekuensi hasil pengamatan

\begin{tabular}{|l|c|c|c|c|c|c|c|}
\hline \multirow{2}{*}{$\begin{array}{l}\text { Jenis } \\
\text { Minimarket }\end{array}$} & Produk & Lokasi & Harga & Kenyamanan & Iklan & Pelayanan & Total \\
\cline { 2 - 8 } Indomaret & 650 & fo & fo & fo & fo & fo & fo \\
\hline Alfamart & 750 & 450 & 850 & 900 & 756 & 687 & 4393 \\
\hline Total & 1400 & 1000 & 1550 & 1700 & 1443 & 1385 & 8478 \\
\hline
\end{tabular}

3. Cari nilai Frekuensi yang Diharapkan (fe)

fe untuk setiap sel $=($ Total Baris $)($ Total Kolom $)$

Total Keseluruhan

Misalkan fe untuk Produk pada Indomaret $=(4393)(1400) / 8478=725$

Demikian untuk perhitungan fe pada bagian selanjutnya.

Tabel 19. Perhitungan uji- Chi-Square

\begin{tabular}{|l|r|r|r|r|r|r|r|r|}
\hline \multirow{2}{*}{$\begin{array}{l}\text { Jenis } \\
\text { Minimarket }\end{array}$} & \multicolumn{2}{|c|}{ Produk } & \multicolumn{2}{c|}{ Lokasi } & \multicolumn{2}{c|}{ Harga } & \multicolumn{2}{c|}{ Kenyamanan } \\
\cline { 2 - 9 } & \multicolumn{1}{|l|}{ fo } & fe & \multicolumn{1}{l|}{ fo } & fe & \multicolumn{1}{l|}{ fo } & \multicolumn{1}{l|}{ fe } & \multicolumn{1}{l|}{ fo } & \multicolumn{1}{l|}{ fe } \\
\hline Indomaret & 650 & 725 & 550 & 518 & 850 & 803 & 900 & 881 \\
\hline Alfamart & 750 & 675 & 450 & 482 & 700 & 747 & 800 & 819 \\
\hline & 1400 & 1400 & 1000 & 1000 & 1550 & 1550 & 1700 & 1700 \\
\hline
\end{tabular}


Lanjutan Tabel 19. Perhitungan uji- Chi-Square

\begin{tabular}{|l|r|r|r|r|c|c|}
\hline \multirow{2}{*}{ Jenis } & \multicolumn{2}{|c|}{ Iklan } & \multicolumn{2}{c|}{ Pelayanan } & \multicolumn{2}{c|}{ Total } \\
\cline { 2 - 7 } Minimarket & \multicolumn{1}{|c|}{ fo } & \multicolumn{1}{|c|}{ fe } & \multicolumn{1}{l|}{ fe } & \multicolumn{1}{c|}{ fo } & fe \\
\hline Indomaret & \multicolumn{1}{|c|}{748} & 687 & 717 & 4393 & 4393 \\
\hline Alfamart & 687 & 695 & 698 & 667 & 4085 & 4085 \\
\hline & 1443 & 1443 & 1385 & 1385 & 8478 & 8478 \\
\hline
\end{tabular}

4. Hitung nilai Chi- Square $\left(\chi^{2}\right)$

$$
\begin{aligned}
\chi^{2}= & (650-725)^{2} / 725+(550-518)^{2} / 518+(850-803)^{2} / 803+(900-881)^{2} / 881+ \\
& (756-748)^{2} / 748+(687-717)^{2} / 717+(750-675)^{2} / 675+(450-482)^{2} / 482+ \\
& (700-747)^{2} / 747+(800-819)^{2} / 819+(687-695)^{2} / 695+(698-667)^{2} / 667 \\
\chi^{2}= & 7.84+1.95+2.73+0.42+0.09+0.11+8.43+2.10+2.94+0.42+ \\
& 0.09+1.31 \\
\chi^{2}= & 28.4
\end{aligned}
$$

5. Tentukan kriteria pengujian

- Jika $\chi^{2}$ hitung $\leq \chi^{2}$ tabel, maka Ho diterima.

- Jika $\chi^{2}$ hitung $>\chi^{2}$ tabel, maka Ho ditolak.

6. Tentukan nilai $\chi 2$ Tabel

- Taraf signifikansi $(\alpha)=0,05$

- $\mathrm{Df}=($ Baris -1$)($ Kolom - 1$)=(2-1)(6-1)=5$

- $\chi^{2}$ Tabel $=11.07$

7. Bandingkan $\chi^{2}$ hitung dengan $\chi^{2}$ tabel

$\chi^{2}$ hitung $=28.4 \geq \chi^{2}$ Tabel $=11.07$ maka Ho ditolak dan H1 diterima , berarti ada perbedaan persepsi konsumen atas faktor penentu tempat belanja mengenai produk, lokasi, harga, kenyamanan berbelanja, iklan, dan pelayanan karyawan yang dimiliki oleh Indomaret dan Alfamart

\section{- Pembahasan}

Berdasarkan hasil pengujian hipotesa dengan Chi- Square $\left(\chi^{2}\right)$ diketahui bahwa terdapat perbedaan yang signifikan antara persepsi konsumen Indomaret dengan persepsi konsumen Alfamart hal tersebut dapat diketahui dari penjelasan per-indikator berikut : Analisis persepsi konsumen Indomaret dengan persepsi konsumen Alfamart terhadap lokasi berdirinya, kelengkapan produk yang ditawarkan, harga yang ditawarkan dan iklan yang disampaikan kedua minimarket tersebut diketahui memiliki perbedaan yang signifikan. Sedangkan analisis persepsi konsumen Indomaret dengan persepsi konsumen Alfamart terhadap pemberian kenyamanan dalam berbelanja dan pelayanan yang diberikan kepada konsumen memiliki perbedaan yang signifikan dalam arti Alfamart lebih unggul.

Menurut pendapat Tajwini Rofian, Majalah marketing: 2004, menyatakan karateristik toko satu dengan yang lainya meski hampir sama dapat memiliki penjualan yang berbeda seperti Indomaret dan Alfamart yang biasanya 
berdampingan dan memiliki karateristik toko yang hampir sama setelah diadakan penelitian ternyata sesuai.

Selain kriteria di atas ternyata setelah diteliti terbukti bahwa konsumen memilih toko juga berdasarkan oleh citra Minimarket tersebut dan menurut responden, Indomaret lebih baik dalam meyakinkan konsumen. Hal ini juga sesuai dengan teori berikut, citra toko pada giliranya mempengaruhi pilihan toko dan produk akhir atau pembelian merek. Jika pengalaman masa lalu memuaskan, maka pilihan akan bersifat kebiasaan. Kecuali jika faktor- faktor lain berubah sejak kunjungan terahir (Engel,1995: 252).

\section{KESIMPULAN}

Berdasarkan hasil pembahasan dapat diambil beberapa kesimpulan yaitu :

1. Adanya perbedaan persepsi konsumen Indomaret dengan persepsi konsumen Alfamart pada indikator lokasi, kelengkapan produk yang ditawarkan, harga dan iklan. Perbedaan yang dimaksudkab di atas bahwa Indomaret lebih unggul di bandingkan dengan Alfamart. Sedangkan dari segi kenyamanan berbelanja dan pelayanan yang diberikan mempunyai perbedaan yang signifikan dalam arti Alfamart lebih unggul dibandingkan dengan Indomaret .

2. Berdasarkan hasil pengujian hipotesa dengan Chi- Square $\left(\chi^{2}\right)$ diketahui bahwa terdapat perbedaan yang signifikan antara persepsi konsumen Indomaret dengan persepsi konsumen Alfamart. Hal ini ditunjukkan dengan nilai $\chi^{2}$ hitung $\left(\chi^{2}=28.4\right)>\chi^{2}$ tabel $\left(\chi^{2}\right.$ tabel $\left.=11,07\right)$.

\section{SARAN-SARAN}

\section{$>$ Indomaret}

1. Penting bagi pihak manajemen Indomaret untuk menyempurnakan kebijakan yang berhubungan dengan kenyamanan dalam berbelanja seperti kemudahan mobilitas konsumen saat berbelanja dan kualitas pelayanan.

2. Terdapat perbedaan penilaian konsumen pada beberapa faktor produk, lokasi, harga, kenyamanan berbelanja, iklan, dan pelayanan karyawan yang dimiliki oleh Indomaret, berdasarkan perbedaan karakteristik konsumen. Berdasarkan hal tersebut penting bagi manajemen Indomaret untuk dapat memahami perilaku konsumen dalam berbelanja. Manajemen Indomaret harus mampu memberikan layanan secara spesifik pada masing-masing konsumen dengan karakteristik yang berbeda.

3. Memberikan hadiah yang lebih menarik dan mengundang banyak minat konsumen, contohnya: dengan pengumpulan poin yang dapat diundi setiap tahun nya, apabila point tersebut paling banyak maka akan mendapatkan hadiah yang menarik seperti motor dan tidak hanya memberikan berupa potongan harga atau vocer belanja. 


\section{Alfamart}

1. Lokasi adalah faktor yang paling dominan bagi konsumen untuk berbelanja di Indomaret. Berdasarkan hal tersebut maka penting bagi manajemen Indomaret untuk menentukan lokasi yang strategis untuk mendirikan toko. Manajemen Indomaret sebaiknya mendirikan toko di pusat-pusat/ konsentrasi masyarakat.

2. Terdapat perbedaan penilaian konsumen pada beberapa faktor produk, lokasi, harga, kenyamanan berbelanja, iklan, dan pelayanan karyawan yang dimiliki oleh Alfamart, berdasarkan perbedaan karakteristik konsumen. Berdasarkan hal tersebut penting bagi manajemen Alfamart untuk dapat memahami perilaku konsumen dalam berbelanja.

3. Pada bagian luar Alfamart sebaik nya di beri fasilitas yang lebih memadai, contohnya: dengan diberikannya layanan Wifi dan tempat untuk duduk- duduk dan meja kecil, untuk tempat para konsumen beristirahat sejenak menikmati apa yang konsumen tersebut belanjakan di Alfamart. Dengan begitu akan menambah kenyamanan berbelanja konsumen.

4. Perlu ditambahkannya lokasi Alfamart di jalan yang strategis karena lokasi adalah faktor yang paling dominan bagi konsumen untuk berbelanja di Alfamart. Berdasarkan hal tersebut maka penting bagi manajemen Indomaret maupun Alfamart untuk menentukan lokasi yang strategis untuk mendirikan toko. Manajemen Alfamart sebaiknya mendirikan toko di pusat-pusat/ konsentrasi masyarakat.

5. Memberikan hadiah yang lebih menarik dan mengundang banyak minat konsumen, contohnya: dengan pengumpulan poin yang dapat diundi setiap tahun nya, apabila point tersebut paling banyak maka akan mendapatkan hadiah yang menarik seperti motor dan tidak hanya memberikan berupa potongan harga atau vocer belanja.

\section{DAFTAR PUSTAKA}

Amir, M. Taufiq. 2005, Dinamika Pemasaran: Jelajahi \& Rasakan, . Jakarta: PT. RajaGrafindo Persada.

Basu Swastha. 2002, Manajemen Pemasaran. Edisi Kedua. Cetakan Kedelapan. Jakarta: Penerbit Liberty

Fandy Tjiptono,2000, Manajemen Jasa, Andi Offset, Yogyakarta. ,2001, Strategi Bisnis dan Manajemen, Andi Offset, Yogyakarta.

Fandi Tjiptono dan Gregorius Candra .2005. Service, Quality, and Satisfaction. Yogyakarta: Andi Offset. 
J. Setiadi, Nugroho, 2003, "Perilaku Konsumen Konsep dan Implikasi untuk Strategi dan Penelitian Pemasaran". Jakarta: Kencana.

Kolcaba, Katherine. 2003, Comfort Theory And Practice: A Vision For Holistic Health Care And Research : New York: Spinger Publishing Company.

Kotler, Philip .2003. Marketing Management. New Jersey: Prentice Hall. 2000, Marketing Management : Analysis Planning Implemebtation and Control, Millenium Edition, Englewood Cliffs, New Jersey : Prentice Hall, Inc.

Kotler dan Amstrong. 2001. Prinsip - prinsip Pemasaran . Jilid 1 dan 2.Edisi 12. Jakarta: Erlangga

2008, Prinsip - prinsip Pemasaran, Jilid 1, Erlangga, Jakarta

Lupiyoadi, Rambat, 2001, Manajemen Pemasaran Jasa : Teori dan Praktik, Penerbit Salemba Empat, Edisi Pertama, Jakarta.

Rangkuti, Freddy .2003. Riset Pemasaran. Jakarta: Gramedia Pustaka Ulama

Santono, Singgih dan Tjiptono, Fandy, 2001. Riset Pemasaran: Konsep dan Aplikasi dengan SPSS, Edisi Pertama, Jakarta: Alex Media Komputindo

Schiffman dan Kanuk. 2000. Perilaku konsumen. Edisi 7. Jakarta: Indeks

Sugiyono, 1994, Statistik Untuk Penelitian, Alfabeta, Bandung.

Sumarwan, Ujang. (2003). “ Perilaku Konsumen “. Penerbit Ghalia Indonesia, Jakarta

Yazid. 1999, Pemasaran Jasa, Konsep dan Implementasi Yogyakarta : Fakultas Ekonomi UII 